University of Nebraska - Lincoln

DigitalCommons@University of Nebraska - Lincoln

Sociology Department, Faculty Publications

Sociology, Department of

2020

The Politics of Religious Nones

Philip Schwadel

Follow this and additional works at: https://digitalcommons.unl.edu/sociologyfacpub

Part of the Family, Life Course, and Society Commons, and the Social Psychology and Interaction Commons

This Article is brought to you for free and open access by the Sociology, Department of at DigitalCommons@University of Nebraska - Lincoln. It has been accepted for inclusion in Sociology Department, Faculty Publications by an authorized administrator of DigitalCommons@University of Nebraska - Lincoln. 


\title{
The Politics of Religious Nones
}

\author{
Philip Schwadel \\ Department of Sociology, University of Nebraska-Lincoln \\ Correspondence - Philip Schwadel, Department of Sociology, University of Nebraska-Lincoln, \\ 740 Oldfather Hall, Lincoln, NE 68588-0324. E-mail: pschwadel2@unl.edu
}

\begin{abstract}
Americans with no religious affiliation (aka religious "Nones") are not a politically homogeneous community. Just as there are political differences between groups of Christians, there are political differences between groups of religious Nones. I use nationally representative survey data to examine the political activities and perspectives of atheists, agnostics, and those who are "nothing in particular." Results show that Americans who report that their religion is nothing in particular are relatively uninterested in politics and unlikely to be politically active; atheists are relatively liberal and likely to experience political conflict and follow political news; and agnostics are particularly likely to vote and feel politically isolated from their families. In many ways, the "softer" secularism of those who are nothing in particular is politically more similar to religious affiliates than the "harder" secularism of agnostics and especially atheists. These results have important implications for the future of American politics as Nones now have the potential to rival evangelical Protestants as a politically relevant constituency.
\end{abstract}

Keywords: affiliation, atheism, none, politics.

Published in Journal for the Scientific Study of Religion (2020) 59(1):180-189

Copyright (c) 2020 The Society for the Scientific Study of Religion. Published by Wiley. Used by permission.

Note: The data used for this study come from Wave 23 of the Pew Research Center's American Trends Panel. The data can be downloaded from the Pew Research Center website: https://www.pewresearch.org/ american-trends-panel-datasets/. 


\section{Introduction}

The number of Americans with no religious affiliation has grown dramatically in recent decades. According to the General Social Survey, while only 6 percent had no religious affiliation in 1991, this increased to 14 percent in 2000, 18 percent in 2010, and 23 percent in 2018 (Smith et al. 2019). Religious “Nones," as they are often called, now constitute one of the three largest religious groups in the nation, along with Catholics and evangelical Protestants. Despite the inextricable mingling of religious and political identities in the U.S. (Schwadel 2017; Wald and Calhoun-Brown 2014), we know little about the political implications of religious nonaffiliation, and even less about political variation among religious Nones (for exceptions, see Baker and Smith 2015 and Frost and Edgell 2018). ${ }^{1}$

Religious Nones are more liberal and more likely to identify as Democrat than the average American (Baker and Smith 2015; Schwadel 2018); and liberal political perspectives may lead some people to become Nones (Campbell et al. 2018; Hout and Fischer 2014; Putnam and Campbell 2010). Aside from partisanship, however, there is a paucity of research on the politics of unaffiliated Americans (Wald and Calhoun-Brown 2014). How is nonaffiliation related to other political behaviors such as voting, feelings of political efficacy, and discussing politics with friends and family? An important contribution of this research note is to examine the relationship between religious nonaffiliation and various political behaviors.

Just as there are politically relevant distinctions within religions, such as between evangelical and mainline Protestants, different types of Nones may be politically distinct from one another. The primary goal of this research note is to compare the political activities and perspectives of three mutually exclusive groups of Nones: atheists, agnostics, and-the largest group-those who report that their religion

\footnotetext{
${ }^{1}$ Baker and Smith (2015) shed light on the politics of different unaffiliated Americans (e.g. atheists vs. agnostics) through bivariate associations. While their analysis is informative, it does not address potential mediating factors such as age, race, and education, which are associated with both religious (see Table 2 ) and political identities (see appendices). The current analysis also explores a wider range of politically relevant outcomes. Frost and Edgell's (2018) analytic approach is more similar to the one employed here, but they focus on civic participation, which is related to but distinct from the political behaviors and perspectives analyzed in this research note.
} 
is "nothing in particular" (henceforth NIP). ${ }^{2}$ I focus on the political implications of these nonreligious identities, not on lack of belief in god(s), which does not always align with atheist and agnostic identification (Smith 2013).

There are several reasons to expect atheists to be politically distinct from agnostics and especially NIPs. Atheism is a highly politicized identity in the U.S. (Edgell et al. 2016; LeDrew 2013). As such, atheism may have specific political repercussions, as well as political antecedents (Campbell et al. 2018). Unlike agnosticism and NIP, atheism is characterized by a hostility toward religion (Streib and Klein 2013). Such hostility is likely to conflict with the perceived religiosity of the Republican constituency and conservative political ideologies that employ religious language (Calfano and Djupe 2009; Claassen et al. 2019). NIP, on the hand, reflects a "softer" secular identity (Kosmin 2007), which may lead to fewer political differences with the religiously affiliated. Consequently,

H1: Atheists are more liberal/Democrat and less conservative/Republican than agnostics and especially NIPs

Atheists, agnostics, and NIPs may differ politically in other ways as well. Atheists are more dogmatic and disagreeable than the average American (Zuckerman, Galen, Pasquale 2016). Atheists are also considerably more likely than other Nones to oppose the influence of religion on politics (Baker and Smith 2015). Atheists' dogmatism, disagreeableness, and vocal opposition to the politicization of religion suggest that they may be relatively effusive about their political positions. Thus,

H2: Atheists are more likely than other Nones to talk about politics

Differences between atheists, agnostics, and NIPs may extend to other forms of political activity as well. There has been considerable political mobilization of American atheists in the last few decades (Cimino and Smith 2014). According to LeDrew (2013:464), contemporary

\footnotetext{
${ }^{2}$ There are many other nonreligious identities in the U.S., such as humanist, freethinker, naturalist, spiritualist, and bright. These groups constitute very small proportions of the American population and thus cannot be analyzed with representative survey data unless the sample is prohibitively large.
} 
atheism "is an essentially political phenomenon." Agnosticism and NIP, on the other hand, are less clearly defined identities; and, as such, may be associated with less political involvement and higher levels of political apathy (Zuckerman et al. 2016). This aligns with Kosmin's (2007) characterization of atheism as a "harder" form of secularism.

H3: Atheists are more involved in politics than are other Nones

This research note expands on previous research by (1) examining crucial distinctions among the Nones, (2) exploring a wide range of political outcomes, and (3) performing multivariate analyses that include potential mediating factors such as age, marital status, education, and region of the country. Results show that Nones differ from the religiously affiliated and from one another on almost all the political outcomes in the analysis. Broadly speaking, NIPs are relatively uninterested in politics; atheists are disproportionately liberal, likely to experience political conflict, and likely to follow political news; and agnostics are particularly likely to vote and feel politically isolated from their families. I conclude by discussing the political implications of growing religious nonaffiliation and nonbelief in the United States.

\section{Data and methods}

The data are from Wave 23 of Pew Research Center's American Trends Panel (ATP), conducted November 29 to December 12, 2016 among 4,183 respondents. The ATP is a nationally representative panel of randomly selected U.S. adults. The survey is self-administered online. Panelists who do not have internet access are provided a tablet and wireless internet connection. For more information on the ATP, see Pew Research Center (2016). The survey is suited to the current research because it includes a variety of questions about political perspectives and behaviors-being soon after the 2016 presidential election-and includes a measure of religious affiliation that distinguishes between atheists, agnostics, and other Nones.

There are 13 dependent variables, which are divided into three broad categories: political behavior and interest, politics and social interactions, and partisanship and ideology (see Table 1 for descriptive statistics). I use three measures of political behavior and interest. 
Table 1: Descriptive statistics

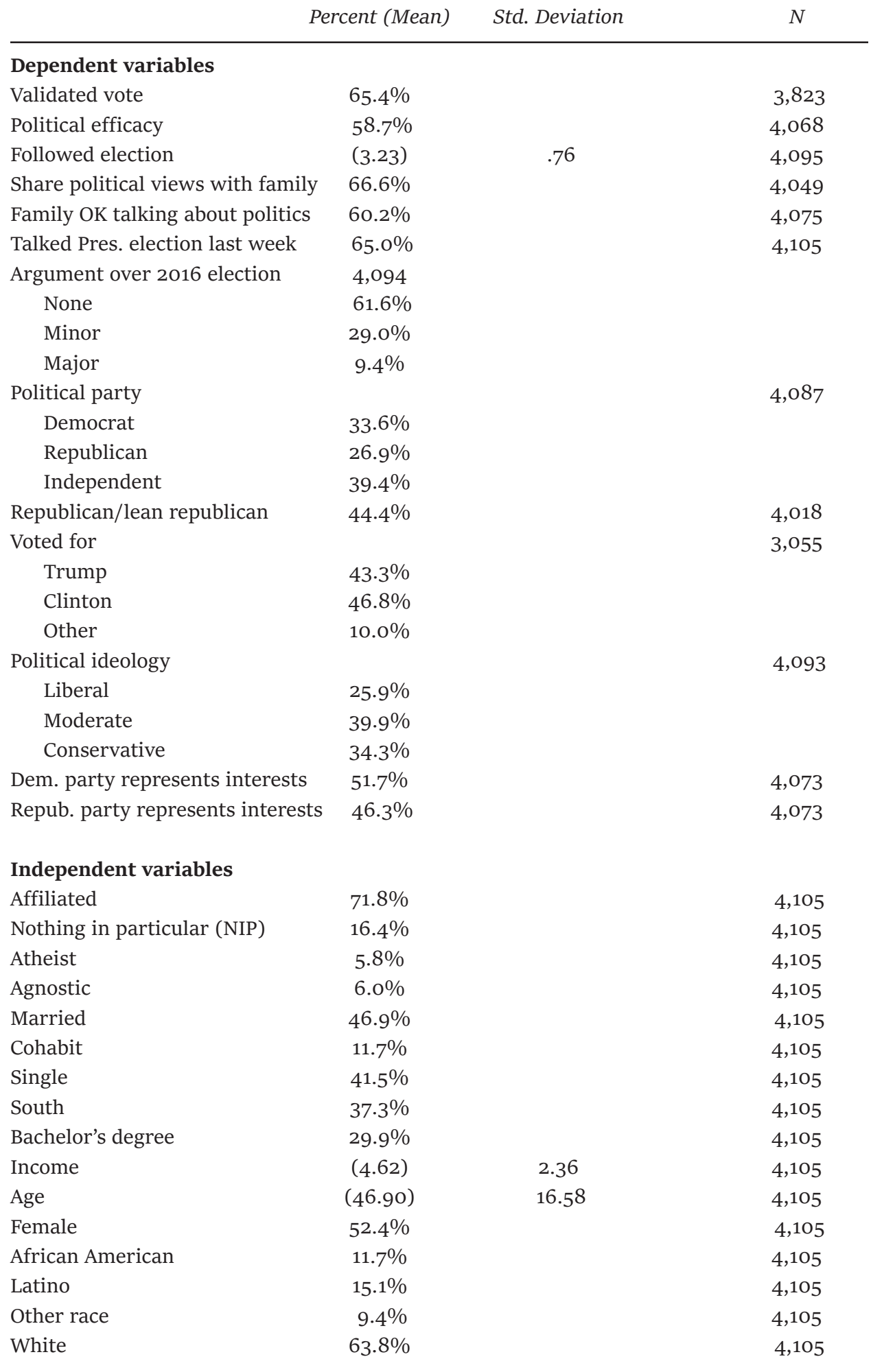

Note: Weighted percentages/means. 
First, a dichotomous variable indicating a validated vote in the 2016 election $(1=$ voted). Self-reports of voting are susceptible to response bias, with as much as 20 percent of nonvoters saying they voted (Cassel 2003). Consequently, I use a validated vote measure rather than self-reports. Ninety-one percent of respondents were matched to five commercial databases that contain information about voter turnout for nearly every U.S. adult. Respondents who were verified as having voted in at least one database are considered to have voted. The proportion of respondents who voted using the validated voter data is much closer to election results than are self-reports of voting (see Pew Research Center 2018 for more on validated vote data). Second, political efficacy is a dichotomous variable coded 1 for support for the idea that "ordinary citizens can do a lot to influence the government in Washington if they are willing to make the effort" and o for the view that "there is not much ordinary citizens can do to influence the government in Washington." Third, political interest is assessed with an ordinal variable gauging how closely respondents followed news about candidates for the 2016 presidential election ( $1=$ not closely at all, 4 = very closely).

Four variables examine social interactions related to politics. First, a dichotomous variable indicating most or almost everyone in the respondent's family shares their political views (vs. a few family members or no one in family shares their political views). Second, a dichotomous variable indicating that the respondent's family is generally okay talking about politics (vs. family tries to avoid talking politics). Third, a dichotomous variable coded 1 for those who had a conversation about the 2016 presidential election in the last seven days and o for those who did not. Fourth, a categorical variable comparing those who report having a major argument about the 2016 election, a minor argument, and no argument about the election.

The final set of dependent variables examines party and ideology. Political party is a categorical variable: Democrat, Republican, and Independent/other party. Most Independents lean toward the Democratic or Republican Party (Klar and Krupnikov 2016; Pew Research Center 2019). Thus, the second party measure is a dichotomous variable coded 1 for those who are Republican or lean toward the Republican Party and o for those who are Democrat or lean toward the 
Democratic Party. ${ }^{3}$ Ideology is a categorical variable: conservative/ very conservative, moderate, and liberal/very liberal. Another categorical variable assesses who the respondent voted for in the 2016 presidential election variable: Donald Trump, Hillary Clinton, or another candidate (nonvoters removed from model). The final two dependent variables are dichotomous measures of agreeing that the Republican (or Democratic) "party represents the interests of people like you" very or somewhat well (vs. not too well or not at all).

The focal independent variables are dummy variables for different categories of self-identified religious nonaffiliates: atheists ( $N=$ 269), agnostics $(N=284)$, and NIPs $(N=529)$. Religious affiliates ( $N$ $=3,023$ ) serve as the omitted reference group. Full models include controls for sex (female $=1$, male $=0$ ), race (dummy variables for African American, Latino, and other race, with White as the reference group), education (bachelor's degree $=1$, no bachelor's $=0$ ), marital status (dummy variables for married and cohabiting, with not currently married or cohabiting as reference group), region (South Census Region $=1$, other regions $=0$ ), family income $(1=$ less than $\$ 10,000,9=\$ 150,000$ or more), and age (19 to 93).

Table 2 highlights the importance of including the control variables in the models by showing that they vary considerably across the religious affiliation categories. For instance, affiliated respondents are relatively likely to be married, older, and live in the South. There is also considerable variation among the Nones. Atheists, for example, are more likely than NIPs to be married and male; agnostics are the most likely to have a bachelor's degree; and NIPs have considerably lower family incomes than either atheists or agnostics.

I employ three types of regression models: multinomial logistic models for categorical dependent variables (political party, ideology, vote choice, and political arguments), ordinal logistic models for the one ordinal dependent variable (following election news), and binary logistic models for the remaining dependent variables, which are all dichotomous. For each dependent variable, there is a partial model

\footnotetext{
${ }^{3}$ After respondents are asked about their party affiliation, a follow-up question about leaning toward the Democratic or Republican Party is asked of all respondents who do not identify as Democrat or Republican. Ninety-one of the 1,561 respondents who received the party lean question refused to answer (which includes the 19 respondents who refused to answer the party affiliation question). Those 91 respondents are removed from the analysis of Republican/Lean Republican.
} 
Table 2: Demographic variables within religious affiliation categories

\begin{tabular}{lrrrr} 
& Affiliated & NIP & Atheist & Agnostic \\
\hline Percent married & $50.8 \%$ & $35.7 \%$ & $40.3 \%$ & $36.2 \%$ \\
Percent cohabit & $8.6 \%$ & $21.2 \%$ & $15.5 \%$ & $18.6 \%$ \\
Percent south & $40.9 \%$ & $29.1 \%$ & $22.0 \%$ & $30.5 \%$ \\
Percent bachelor's degree & $29.4 \%$ & $22.9 \%$ & $40.0 \%$ & $44.9 \%$ \\
Mean income & 4.56 & 4.33 & 5.59 & 5.17 \\
Mean age & 49.25 & 40.90 & 40.52 & 41.37 \\
Percent female & $54.4 \%$ & $51.4 \%$ & $33.5 \%$ & $49.6 \%$ \\
Percent African American & $12.8 \%$ & $10.5 \%$ & $6.8 \%$ & $7.4 \%$ \\
Percent Latino & $16.0 \%$ & $18.1 \%$ & $5.4 \%$ & $5.1 \%$ \\
Percent other race & $10.0 \%$ & $9.2 \%$ & $8.7 \%$ & $3.0 \%$ \\
\hline
\end{tabular}

Notes: Weighted; $N=4,105$.

NIP $=$ nothing in particular.

with religious affiliation/identification measures but no controls, and a full model that also includes control variables. All models were conducted in Stata 14 and weighted to account for differential probabilities of selection into the panel and differential nonresponse to the panel recruitment survey. To highlight the substantive importance of the findings, the results section presents predicted probabilities for the religiously affiliated, NIPs, atheists, and agnostics (at the means of other variables in model). Significance tests are conducted for each pairwise comparison. ${ }^{4}$ Because atheism and agnosticism are relatively rare identities, and thus, there are fewer respondents in those categories, I flag differences that are significant at $\mathrm{p}<.1$ as well as $\mathrm{p}<.05$. Complete model results are shown in the appendices.

\section{Results}

Table 3 reports predicted probabilities for religious affiliates, NIPs, atheists, and agnostics for all 13 political outcomes. Starting with voting, the most basic form of democratic political participation, the partial model shows that religious affiliates (probability $=.67$ ) and

\footnotetext{
4 Predicted probabilities and related significance tests are derived using the margins and $p w$ compare (at means) postestimation options in Stata.
} 
Table 3: Predicted probabilities from partial and full models of political activities and perspectives

\begin{tabular}{|c|c|c|c|c|c|c|c|c|c|}
\hline \multirow[b]{3}{*}{ Dependent Variable } & \multicolumn{8}{|c|}{ Independent Variables } & \multirow[b]{3}{*}{$N$} \\
\hline & \multicolumn{4}{|c|}{ Partial model } & \multicolumn{4}{|c|}{ Full model } & \\
\hline & Affiliated & $\begin{array}{l}N I P \\
\text { (a) }\end{array}$ & $\begin{array}{l}\text { Atheist } \\
\text { (b) }\end{array}$ & $\begin{array}{l}\text { Agnostic } \\
\text { (c) }\end{array}$ & Affiliated & $\begin{array}{r}N I P \\
\text { (a) }\end{array}$ & $\begin{array}{l}\text { Atheist } \\
\text { (b) }\end{array}$ & $\begin{array}{l}\text { Agnostic } \\
\text { (c) }\end{array}$ & \\
\hline \multicolumn{10}{|l|}{ Political Behavior and Interest } \\
\hline Validated vote & $.67^{\mathrm{a}}$ & $.54^{\mathrm{c}}$ & .66 & .75 & .70 & $.63^{\mathrm{c}}$ & .67 & .76 & 3,823 \\
\hline Political efficacy & $.6 \mathrm{o}^{\mathrm{a}}$ & .51 & .59 & .59 & $.6 \mathrm{o}^{\mathrm{a}}$ & .51 & .59 & .61 & 4,068 \\
\hline Followed election very closely & $.47^{\mathrm{a}, \mathrm{b}}$ & $.40^{\mathrm{b}}$ & .62 & .51 & $.46^{\mathrm{b}}$ & $.43^{\mathrm{b}}$ & .63 & .51 & 4,095 \\
\hline \multicolumn{10}{|l|}{ Politics and social interactions } \\
\hline Share political views $\mathrm{w} /$ family & $.71^{\mathrm{b}, \mathrm{c}}$ & $.69^{c}$ & $.65^{\mathrm{c}}$ & .58 & $.69^{\mathrm{b}, \mathrm{c}}$ & $.65^{\mathrm{c}}$ & .58 & .54 & 4,049 \\
\hline Family OK talking politics & $.62^{\mathrm{a}}$ & .55 & .56 & .54 & .62 & .57 & .54 & .54 & 4,075 \\
\hline Talked Pres. election last week & $.65^{\mathrm{a}, \mathrm{b}}$ & $.54^{\mathrm{b}, \mathrm{c}}$ & $.86^{\mathrm{c}}$ & .72 & $.67^{\mathrm{a}, \mathrm{b}}$ & $.58^{\mathrm{b}, \mathrm{c}}$ & $.86^{\mathrm{c}}$ & .71 & 4,105 \\
\hline Argument over 2016 election & & & & & & & & & 4,094 \\
\hline None & $.64^{\mathrm{b}, \mathrm{c}}$ & $.65^{\mathrm{b}, \mathrm{c}}$ & $.36^{\mathrm{c}}$ & .54 & $.63^{\mathrm{a}, \mathrm{b}}$ & $.68^{\mathrm{b}}$ & $.43^{\mathrm{c}}$ & .61 & \\
\hline Minor & $.27^{\mathrm{b}}$ & $.28^{\mathrm{b}}$ & $.50^{c}$ & .36 & $.28^{\mathrm{b}}$ & $.26^{\mathrm{b}}$ & $.44^{\mathrm{c}}$ & .30 & \\
\hline Major & .09 & $.07^{\mathrm{b}}$ & .15 & .10 & $.09^{\mathrm{a}}$ & $.06^{\mathrm{b}}$ & .13 & .09 & \\
\hline \multicolumn{10}{|l|}{ Partisanship and Ideology } \\
\hline Political party & & & & & & & & & 4,087 \\
\hline Democrat & $\cdot 33^{\mathrm{c}}$ & .34 & .37 & .42 & $\cdot 31^{\mathrm{b}, \mathrm{c}}$ & $\cdot 34^{\mathrm{b}, \mathrm{c}}$ & .45 & .49 & \\
\hline Republican & $\cdot 32^{\mathrm{a}, \mathrm{b}, \mathrm{c}}$ & $.17^{\mathrm{b}, \mathrm{c}}$ & .07 & .09 & $\cdot 30^{\mathrm{a}, \mathrm{b}, \mathrm{c}}$ & $.16^{\mathrm{b}, \mathrm{c}}$ & .05 & .06 & \\
\hline Independent & $\cdot 35^{\mathrm{a}, \mathrm{b}, \mathrm{c}}$ & .49 & .56 & .49 & $\cdot 39^{\mathrm{a}, \mathrm{b}}$ & .50 & .50 & .45 & \\
\hline Republican/Lean Republican & $.51^{\mathrm{a}, \mathrm{b}, \mathrm{c}}$ & $\cdot 34^{\mathrm{b}, \mathrm{c}}$ & .18 & .24 & $.5 \mathrm{O}^{\mathrm{a}, \mathrm{b}, \mathrm{c}}$ & $.32^{\mathrm{b}, \mathrm{c}}$ & .12 & .18 & 4,018 \\
\hline Ideology & & & & & & & & & 4,093 \\
\hline Liberal & $.2 \mathrm{O}^{\mathrm{a}, \mathrm{b}, \mathrm{c}}$ & $.34^{\mathrm{b}}$ & $.59^{c}$ & .39 & $.2 \mathrm{O}^{\mathrm{a}, \mathrm{b}, \mathrm{c}}$ & $.33^{\mathrm{b}}$ & $.57^{\mathrm{c}}$ & .35 & \\
\hline Moderate & $.40^{\mathrm{b}}$ & $.42^{\mathrm{b}}$ & $.29^{c}$ & .44 & $.41^{\mathrm{b}}$ & $.42^{\mathrm{b}}$ & $.31^{\mathrm{c}}$ & .47 & \\
\hline Conservative & $.40^{a, b, c}$ & $.24^{\mathrm{b}}$ & .13 & .17 & $\cdot 39^{\mathrm{a}, \mathrm{b}, \mathrm{c}}$ & $.25^{\mathrm{b}}$ & .13 & .17 & \\
\hline Voted For & & & & & & & & & 3,055 \\
\hline Donald Trump & $.5 \mathrm{O}^{\mathrm{a}, \mathrm{b}, \mathrm{c}}$ & .26 & .16 & .22 & $.49^{\mathrm{a}, \mathrm{b}, \mathrm{c}}$ & $.23^{\mathrm{b}}$ & .11 & .17 & \\
\hline Hillary Clinton & $.41^{\mathrm{a}, \mathrm{b}, \mathrm{c}}$ & .60 & .67 & .65 & $.42^{\mathrm{a}, \mathrm{b}, \mathrm{c}}$ & .66 & .75 & .73 & \\
\hline Other & .08 & .15 & .16 & .12 & .09 & .12 & .14 & .09 & \\
\hline Dem. Represents Interests & $.47^{\mathrm{a}, \mathrm{b}, \mathrm{c}}$ & .62 & .62 & .69 & $.47^{\mathrm{a}, \mathrm{b}, \mathrm{c}}$ & $.61^{\mathrm{c}}$ & .68 & .74 & 4,073 \\
\hline Repub. Represents Interests & $\cdot 53^{\mathrm{a}, \mathrm{b}, \mathrm{c}}$ & .33 & .25 & .25 & $\cdot 53^{\mathrm{a}, \mathrm{b}, \mathrm{c}}$ & $.32^{\mathrm{b}, \mathrm{c}}$ & .20 & .21 & 4,073 \\
\hline
\end{tabular}

Notes: NIP = nothing in particular; partial models include only religious affiliation/identification measures; full models also include controls for age, race, sex, education, family income, marital status, and region; models of party, ideology, vote choice, and political arguments are multinomial logistic regressions; models of following election are ordinal logistic regressions; all other models are binary logistic regressions; see appendices for complete model results.

a. Differs significantly from NIP (superscript $=p<.05$, subscript $=p<.1$ ) (two-tailed test).

b. Differs significantly from atheist (superscript $=p<.05$, subscript $=p<.1$ ) (two-tailed test).

c. Differs significantly from agnostic (superscript $=p<.05$, subscript $=p<.1$ ) (two-tailed test).

\section{agnostics (.75) are significantly more likely than NIPs (.54) to vote. In the full model, the difference between affiliates and NIPs is reduced and no longer significant but the probability of voting for agnostics (.76) continues to be higher than for NIPs (.63).}


Continuing with political behaviors and interest, the partial model shows that religiously affiliated Americans (.60) are more likely than NIPs (.51) to report feeling politically efficacious. The affiliated, however, are no more likely than atheists or agnostics (both .59) to feel politically efficacious. These results are largely unaffected by the addition of control variables. Turning to following political news, the results show that religious affiliates (.46) and NIPs (.43) are the least likely to follow election news very closely, and atheists (.63) the most likely (full model). Overall, these results suggest that NIPs are less interested in politics than are atheists and agnostics.

The next set of models focus on social interactions and politics. Atheists (.58) and agnostics (.54) are less likely than religious affiliates (.69) to report sharing political views with their families (full model). NIPs (.65) are not significantly different from religious affiliates, and they are more likely than agnostics to share political views with their families. Despite being less likely to share political views with their families, atheists and agnostics are not significantly less likely than religious affiliates to say it is okay to talk about politics with their families (partial and full models).

Atheists stand out when it comes to conversations and confrontations about politics. The full model of having talked about the presidential election in the last week shows NIPs (.58) are particularly unlikely to have such conversations while atheists (.86) are particularly likely to do so. Religious affiliates (.67) and agnostics (.71) fall in between. Atheists are also relatively likely to have an argument about the election. Atheists (.44) are more likely than the affiliated (.28), NIPs (.26), and agnostics (.30) to have a minor political argument; and they $(.13)$ are more likely $(\mathrm{p}<.1)$ than NIPs $(.06)$ to have a major argument (full model). These results suggest that atheists are particularly politically engaged, and, again, that NIPs as relatively unengaged.

The final set of models examines partisanship and ideology. As expected, all three groups of Nones are all considerably less likely than religious affiliates (.30) to report Republican identification (full model). But there is also notable variation among the Nones, with NIPs (.16) being significantly more likely than atheists (.05) and agnostics (.o6) to identify with the Republican Party. Atheists and agnostics make up for their low rates of Republican identification with high rates of identification with the Democratic Party (.45 and .49, 
respectively). NIPs (.34), on the other hand, are no more likely than religious affiliates (.31) to identify as Democrat. All three groups of Nones are far less likely than religious affiliates (.50) to identify as Republican or lean toward the Republican Party (full model). NIPs (.32) are also more likely than atheists (.12) and agnostics (.18) to identify as Republican or lean toward the Republican Party.

The pattern for ideology is similar to party, though in this case agnostics behave more like NIPs than atheists. In the full model, religious affiliates (.20) are less likely than all three groups of Nones to report being liberal, though atheists (.57) are far more likely than both NIPs (.33) and agnostics (.35) to be liberal. Conversely, religious affiliates (.39) are more likely than all three groups of Nones to identify as conservative, though atheists (.13) are even less likely than NIPs (.25) to report being conservative.

Reflecting the above differences in party and ideology, religious affiliates (.49) are more likely than all three groups of Nones to have voted for Donald Trump, and less likely (.42) to have voted for Hillary Clinton (full model). Atheists (.11) again stand out among the Nones, being about half as likely as NIPs (.23) to have voted for Trump.

When it comes to views of the parties, religious affiliates are far more likely than all three groups of Nones to say the Republican Party represents the interests of people like them, and far less likely to say the Democratic Party represents them. More interesting, however, are the differences among the Nones. In the full models, NIPs (.61) are less likely than agnostics (.74) to say the Democratic Party represents people like them, and NIPs (.32) are more likely than both atheists (.20) and agnostics (.21) to say the Republican Party represents people like them. Overall, the partisanship and ideology results show that NIPs are less liberal/Democratic (or more conservative/Republican) than agnostics and especially atheists.

\section{Discussion and conclusions}

The goal of this research note is to provide clarity on the political perspectives and behaviors of different groups of religious Nones. As previous research shows (e.g., Baker and Smith 2015; Wald and Calhoun-Brown 2014), religious Nones are more liberal than religious 
affiliates, and more likely to identify with the Democratic Party. While this is true of Nones a whole, agnostics, atheists, and NIPs are politically quite different from one another. As the above results show, atheists are more liberal than other Nones,which support Hypothesis 1. Additionally, both atheists and agnostics are more likely than NIPs to support the Democratic Party, and less likely than NIPs to support the Republican Party. These findings suggest that the "softer" secularism (Kosmin 2007) of a NIP identity is more amendable to conservative politics than the "harder" secularism of agnostic and especially atheist identities.

Although some research suggests that religious Nones are relatively unlikely to be politically active (e.g., Jones et al. 2016), the above results paint a more nuanced picture of nonaffiliates' political activities. NIPs-the largest group of Nones-are less likely than the religiously affiliated to vote, but this difference is mediated by the control variables. Even with controls in the model, however, agnostics remain more likely than NIPs to vote. NIPs are also less likely than the religiously affiliated to feel politically efficacious and to talk about the election. These results suggest that NIPs are not very politically active and that they are relatively uninterested in politics. But the same cannot be said of atheists and agnostics. This finding aligns with Frost and Edgell's (2018) analysis of civic participation, where they find that NIPs are relatively uninterested in local community affairs. As Frost and Edgell (2018:433) suggest, NIPs' political apathy may reflect a more marginal status than other Nones due to the "inherent status inconsistency and value uncertainty" of being nothing in particular.

Unlike NIPs, atheists are relatively politically active and interested in politics. They are more likely than agnostics, NIPs, and the religiously affiliated to talk about the presidential election, which supports the second hypothesis. Atheists are also more likely than NIPs and the religiously affiliated to follow news about the election, which lends some support to the third hypotheses. This comports with research on the political mobilization of atheists (Cimino and Smith 2014) and the politicization of contemporary atheism (Edgell et al. 2016; LeDrew 2013). Nonetheless, such political mobilization does not lead atheists to be any more likely than religious affiliates to vote or feel politically efficacious. Overall, the results indicate that agnostics and atheists are often more politically active than NIPs, and on some measures, atheists are more politically active than the religiously affiliated as well. Agnostics' relatively high level of political activity is 
an interesting finding, which may be related to Baker and Smith's (2015) characterization of agnostics as a knowledgeable population with a strong emphasis on philosophy and reason. Additional research is needed to shed light on how agnostics understand the relationship between their religious and political identities.

There is also considerable political variation among the Nones when it comes to families and politics. The results show that atheists and agnostics, but not NIPs, are less likely than religious affiliates to report sharing political values with their families. Their partisanship and liberal leanings likely make them politically distinct from other members of their families. Still, atheists and agnostics are not any more likely to report discomfort with talking to their families about politics. This is surprising not only because atheists and agnostics are often politically different from their families but also because atheists are relatively likely to have arguments about the 2016 election. Qualitative research on how unaffiliated Americans navigate religion, politics, and family could shed light on the ways that agnostics and atheists appear to separate their political differences from their familial interactions.

This research note demonstrates that not only are religiously unaffiliated Americans politically distinct from those with a religious affiliation, but, more importantly, they are politically distinct from one another. Religious Nones are not a monolithic group. Unlike NIPs, atheists and agnostics are almost never Republican, but atheists are far more likely than agnostics to be liberal. How might this affect their support for specific issues and candidates? Atheists are especially likely to follow election news and have conversations about the election. As atheism becomes more common in the United States (Pew Research Center 2015), atheists' political mobilization may become a potent factor in local and national politics. On the other hand, NIPs are relatively uninterested in politics and more likely than other Nones to identify as Republican and conservative. It is possible that a sizable segment of the NIP community may eventually become an important part of the Republican constituency, if the Republican Party can effectively mobilize them. In conclusion, the results here highlight the high levels of internal political diversity among religious nonaffiliates. Now that there are as many Nones as there are Catholics and evangelical Protestants in the United Search., research on religion and politics, and even political projections based on demographic distributions, will have to account for such political diversity. 
Acknowledgments: The author thanks Greg Smith, Courtney Kennedy, Scott Keeter, Jocelyn Kiley, the Editor of JSSR, and the anonymous reviewers for their thoughtful comments on earlier drafts.

\section{References}

Baker, Joseph O. and Buster G. Smith. 2015. American secularism: Cultural contours of nonreligious belief systems. New York, NY: NYU Press.

Campbell, David E., Geoffrey C. Layman, John C. Green, and Nathanael G. Sumaktoyo. 2018. Putting politics first: The impact of politics on Americans religious and secular orientations. American Journal of Political Science 62(3):551-65.

Calfano, Brian Robert and Paul A. Djupe. 2009. God talk: Religious cues and electoral support. Political Research Quarterly 62(2):329-39.

Cassel, Carol A. 2003. Overreporting and electoral participation research. American Politics Research 31:81-92.

Cimino, Richard and Christopher Smith. 2014. Atheist awakening: Secular activism \& community in America. New York, NY: Oxford University Press.

Claassen, Ryan L., Paul A. Djupe, Andrew R. Lewis, and Jacob R. Neiheisel. 2019. Which party represents my group? The group foundations of partisan choice and polarization. Political Behavior https://doi.org/10.1007/ s11109-019-09565-6

Edgell, Penny, Douglas Hartmann, Evan Stewart, and Joseph Gerteis. 2016. Atheists and other cultural outsiders: Moral boundaries and the non-religious in the United States. Social Forces 95(2): 607-38.

Frost, Jacqui and Penny Edgell. 2018. Rescuing the Nones from the reference category: Civic engagement among the nonreligious in America. Nonprofit and Voluntary Sector Quarterly 47(2):417-38.

Hout, Michael and Claude F. Fischer. 2014. Explaining why more Americans have no religious preference: Political backlash and generational succession, 19872012. Sociological Science 1:423-47.

Jones, Robert P.,Daniel Cox, Betsy Cooper, and Rachel Lienesch. 2016. "Exodus: Why Americans are Leaving Religion - and Why They're Unlikely to Come Back.” Public Religion Research Institute. http://www.prri.org/research/ prrirns- poll-nones-atheist-leaving-religion/ (accessed March 5, 2019).

Klar, Samara and Yanna Krupnikov. 2016. Independent politics: How American Disdain for parties leads to political inaction. New York, NY: Cambridge University Press.

Kosmin, Barry A. 2007. Contemporary secularity and secularism. In Secularism \& secularity: Contemporary international perspectives, edited by Barry A. Kosmin and Ariela Keysar, pp. 1-13. Hartford, CT: Trinity College Institute for the Study of Secularism in Society and Culture. 
LeDrew, Stephen. 2013. "Reply: Toward a crticial sociology of atheism: identity, politics, ideology." Sociology of Religion 74(4):464-70.

Pew Research Center. 2015. America's Changing Religious Landscape. https:// www.pewforum.org/2015/05/12/americaschanging-religious-landscape/ (accessed October 29, 2019).

- 2016. Elections Wake, Partisans Assess the State of their Parties, Methodology. https://www.people-press.org/2016/12/20/methodology-81/ (accessed June 18, 2019).

- 2018. Commercial Voter Files and the Study of U.S. Politics. https://www. pewresearch.org/methods/2018/02/15/commercial-voter-files-and-the-studyof-u-s-politics/ (accessed June 18, 2019).

— 2019. Political Independents: Who They Are, What They Think. https:// www.people-press.org/2019/03/14/political-independents-who-they-are-whatthey-think/ (accessed June 18, 2019).

Putnam, Robert D., and David E. Campbell. 2010. American grace: How religion divides and unites us. New York, NY: Simon \& Schuster.

Schwadel, Philip. 2017. The republicanization of evangelical protestants in the United States: An examination of the sources of political realignment. Social Science Research 62:238-54.

-2018. The political implications of religious non-affiliation in emerging adulthood. Journal of Religion \& Society Supplement 17:149-66.

Smith, Jesse M. 2013. Creating a godless community: the collective identity work of contemporary American atheists. Journal for the Scientific Study of Religion 52(1):80-99.

Smith, Tom W., Michael Davern, Jeremy Freese, and Stephen L. Morgan. 2019. General social surveys, 1972-2018, cumulative codebook. Chicago, IL: University of Chicago Press.

Streib, Heinz and Constantin Klein. 2013. Atheists, agnostics, and apostates. In APA handbook of psychology, religion, and spirituality (Vol. 1): Context, theory, and research, edited by Pargament, Kenneth I., Julie J. Exline, and James W. Jones, pp. 713-28. Washington, DC: American Psychological Association.

Wald, Kenneth D., Calhoun-Brown, Allison. 2014. Religion and politics in the United States, seventh ed. Lanham, MD: Rowman \& Littlefield Publisher, Inc.

Zuckerman, Phil, Like W. Galen, and Frank L. Pasquale. 2016. The nonreligious: Understanding secular people \& societies. New York, NY: Oxford University Press. 


\section{Appendices for "The Politics of Religious Nones"}

Table A1. Binary Logistic Regressions of Voting and Political Efficacy, and Ordinal Logistic Regressions of Followed Election

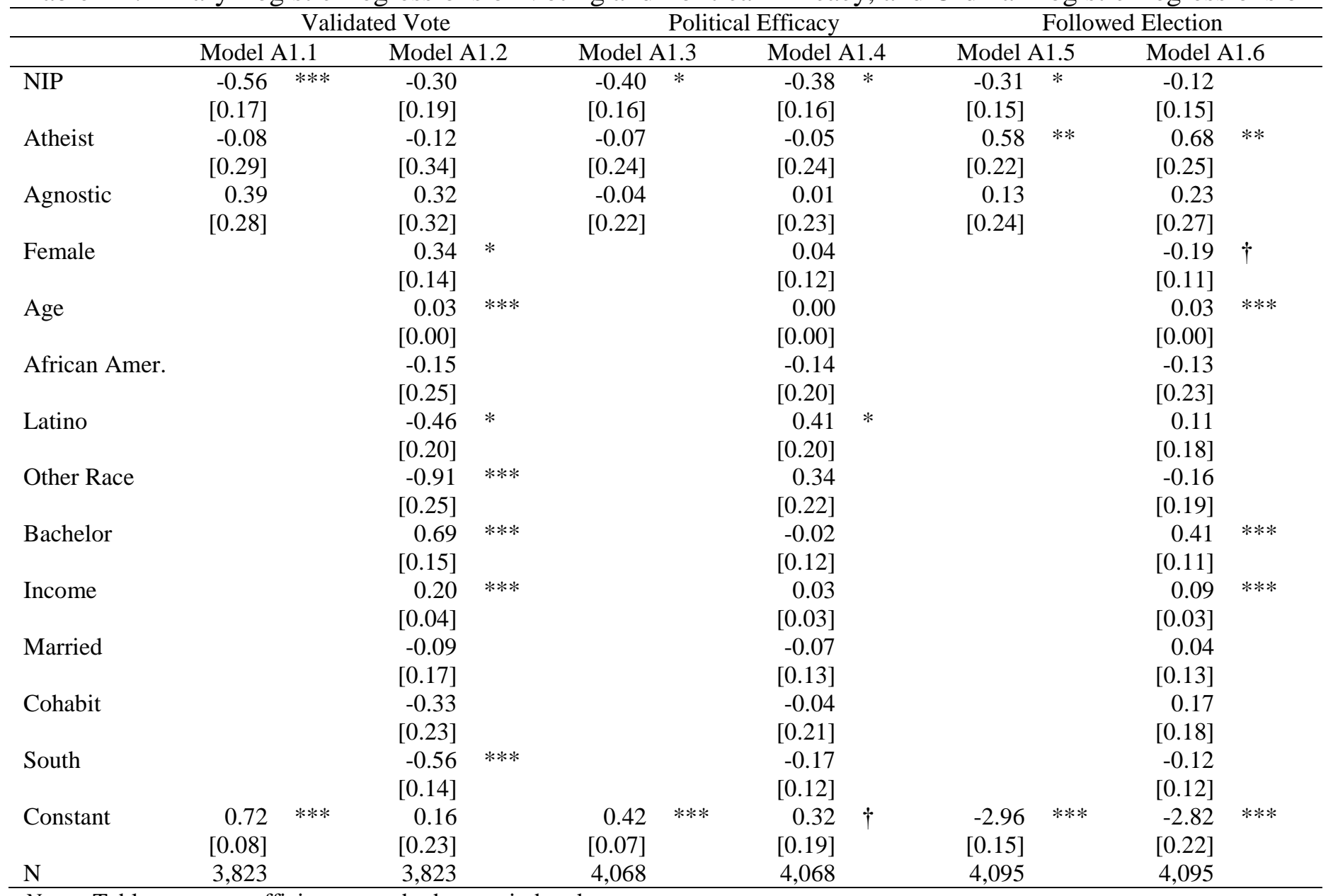

Notes: Table reports coefficients, standard errors in brackets.

$\dagger \mathrm{p}<.1, * \mathrm{p}<.05, * * \mathrm{p}<.01, * * * \mathrm{p}<.001$ (two-tailed test) 
Table A2. Binary Logistic Regressions of Sharing Political Views with Family, Family Okay Talking about Politics, and Talking about the Presidential Election in the Last Week

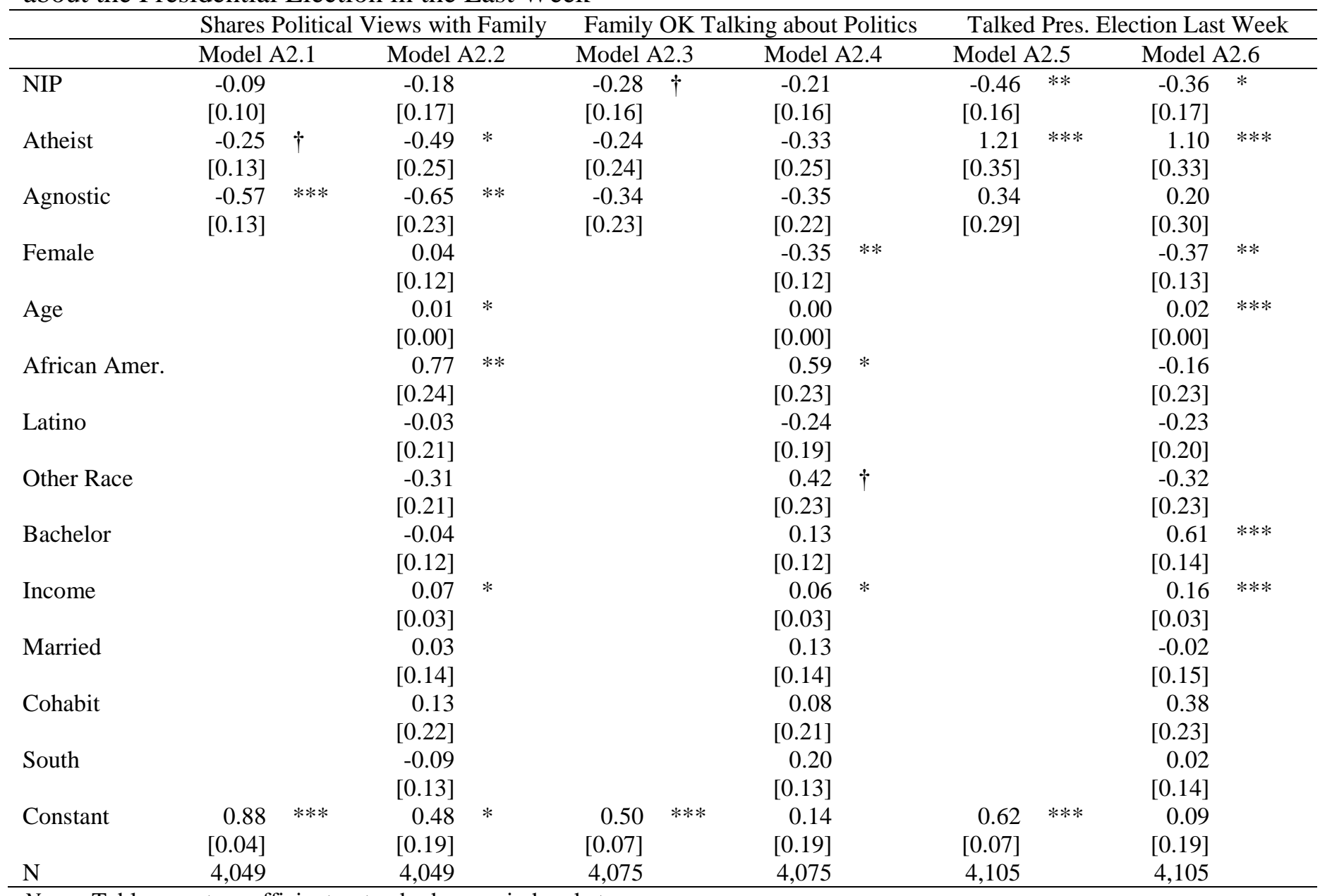

Notes: Table reports coefficients, standard errors in brackets.

$\dagger \mathrm{p}<.1,{ }^{*} \mathrm{p}<.05, * * \mathrm{p}<.01, * * * \mathrm{p}<.001$ (two-tailed test) 
Table A3. Multinomial Logistic Regressions of Argument over Election (Dependent Variable Reference Category = No Argument)

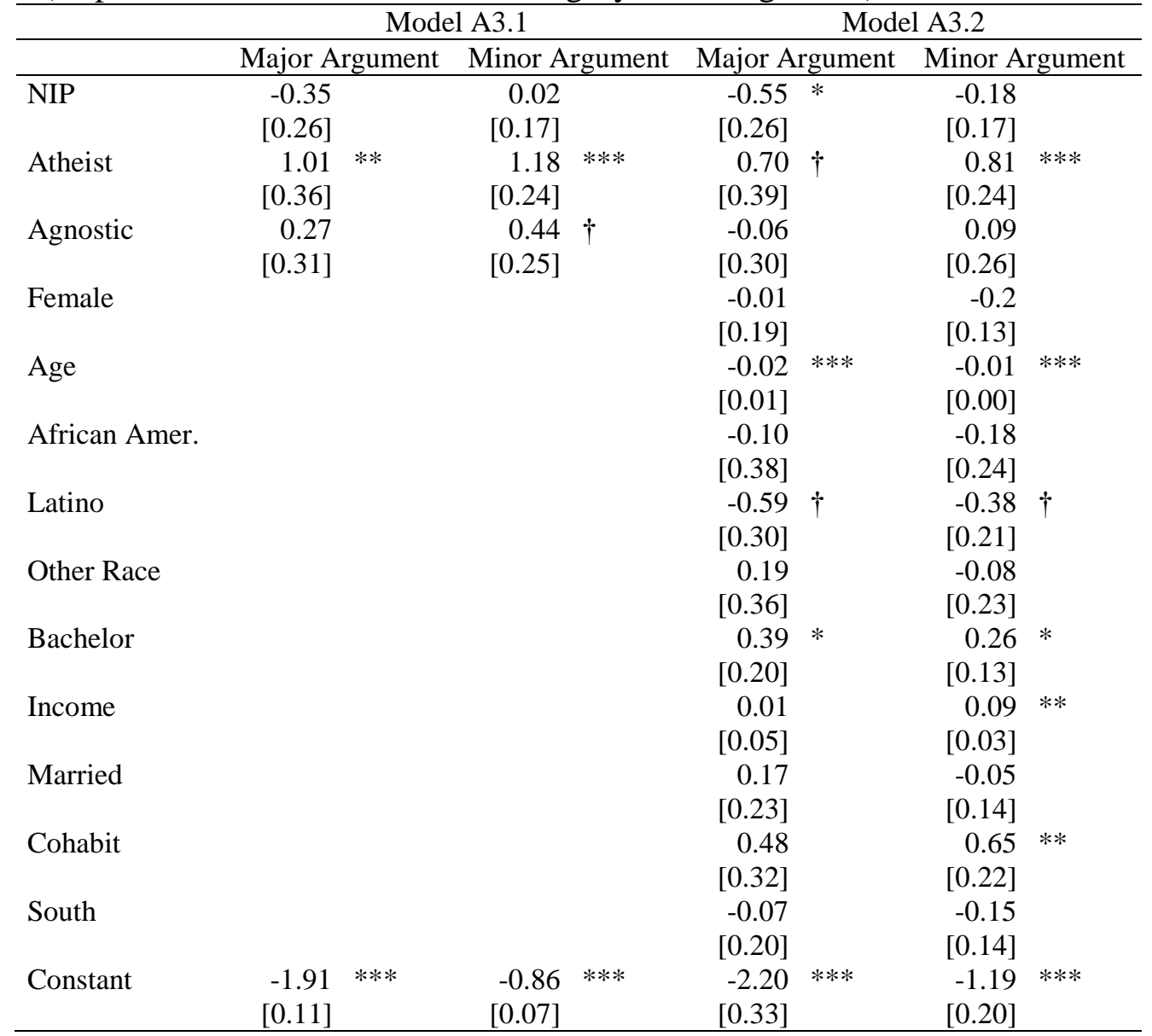

Notes: Table reports coefficients, standard errors in brackets, $\mathrm{N}=4,094$.

$\dagger \mathrm{p}<.1,{ }^{*} \mathrm{p}<.05,{ }^{* *} \mathrm{p}<.01,{ }^{* * *} \mathrm{p}<.001$ (two-tailed test) 
Table A4. Multinomial Logistic Regressions of Party Identification (Dependent Variable Reference Category = Independent/Other Party)

\begin{tabular}{|c|c|c|c|c|c|c|c|}
\hline & \multicolumn{3}{|c|}{ Model A4.1 } & \multicolumn{4}{|c|}{ Model A4.2 } \\
\hline & Democrat & Republic & & Democra & & Republic & \\
\hline \multirow[t]{2}{*}{$\overline{\mathrm{NIP}}$} & $-0.32 \dagger$ & -0.98 & $* * *$ & -0.13 & & -0.86 & $* * *$ \\
\hline & {$[0.18]$} & {$[0.22]$} & & {$[0.18]$} & & {$[0.22]$} & \\
\hline \multirow{2}{*}{ Atheist } & -0.36 & -1.95 & $* * *$ & 0.12 & & -2.00 & $* * *$ \\
\hline & [0.23] & [0.59] & & {$[0.23]$} & & [0.59] & \\
\hline \multirow[t]{2}{*}{ Agnostic } & -0.09 & -1.66 & $* * *$ & 0.32 & & -1.69 & $* * *$ \\
\hline & {$[0.24]$} & [0.35] & & {$[0.25]$} & & {$[0.37]$} & \\
\hline \multirow[t]{2}{*}{ Female } & & & & 0.61 & $* * *$ & 0.08 & \\
\hline & & & & {$[0.14]$} & & {$[0.15]$} & \\
\hline \multirow[t]{2}{*}{ Age } & & & & 0.01 & $* * *$ & 0.01 & $*$ \\
\hline & & & & {$[0.00]$} & & {$[0.00]$} & \\
\hline \multirow{2}{*}{ African Amer. } & & & & 1.43 & $* * *$ & -1.78 & $* * *$ \\
\hline & & & & {$[0.22]$} & & {$[0.50]$} & \\
\hline \multirow[t]{2}{*}{ Latino } & & & & 0.95 & $* * *$ & -1.05 & $* * *$ \\
\hline & & & & {$[0.21]$} & & {$[0.27]$} & \\
\hline \multirow[t]{2}{*}{ Other Race } & & & & 0.58 & * & -0.72 & * \\
\hline & & & & {$[0.24]$} & & {$[0.30]$} & \\
\hline \multirow{2}{*}{ Bachelor } & & & & 0.25 & $\dagger$ & -0.34 & * \\
\hline & & & & [0.14] & & [0.15] & \\
\hline \multirow[t]{2}{*}{ Income } & & & & -0.01 & & 0.05 & \\
\hline & & & & {$[0.03]$} & & [0.04] & \\
\hline \multirow[t]{2}{*}{ Married } & & & & -0.06 & & 0.04 & \\
\hline & & & & {$[0.16]$} & & {$[0.17]$} & \\
\hline \multirow[t]{2}{*}{ Cohabit } & & & & -0.12 & & -0.52 & $\dagger$ \\
\hline & & & & {$[0.24]$} & & {$[0.31]$} & \\
\hline \multirow[t]{2}{*}{ South } & & & & -0.13 & & 0.30 & $\dagger$ \\
\hline & & & & {$[0.15]$} & & {$[0.16]$} & \\
\hline \multirow[t]{2}{*}{ Constant } & -0.07 & -0.08 & & -0.81 & $* * *$ & -0.04 & \\
\hline & [0.08] & [0.08] & & {$[0.21]$} & & {$[0.25]$} & \\
\hline
\end{tabular}

Notes: Table reports coefficients, standard errors in brackets, $\mathrm{N}=4,087$.

$\dagger \mathrm{p}<.1, * \mathrm{p}<.05, * * \mathrm{p}<.01, * * * \mathrm{p}<.001$ (two-tailed test) 
Table A5. Multinomial Logistic Regressions of Political Ideology (Dependent Variable Reference Category = Moderate)

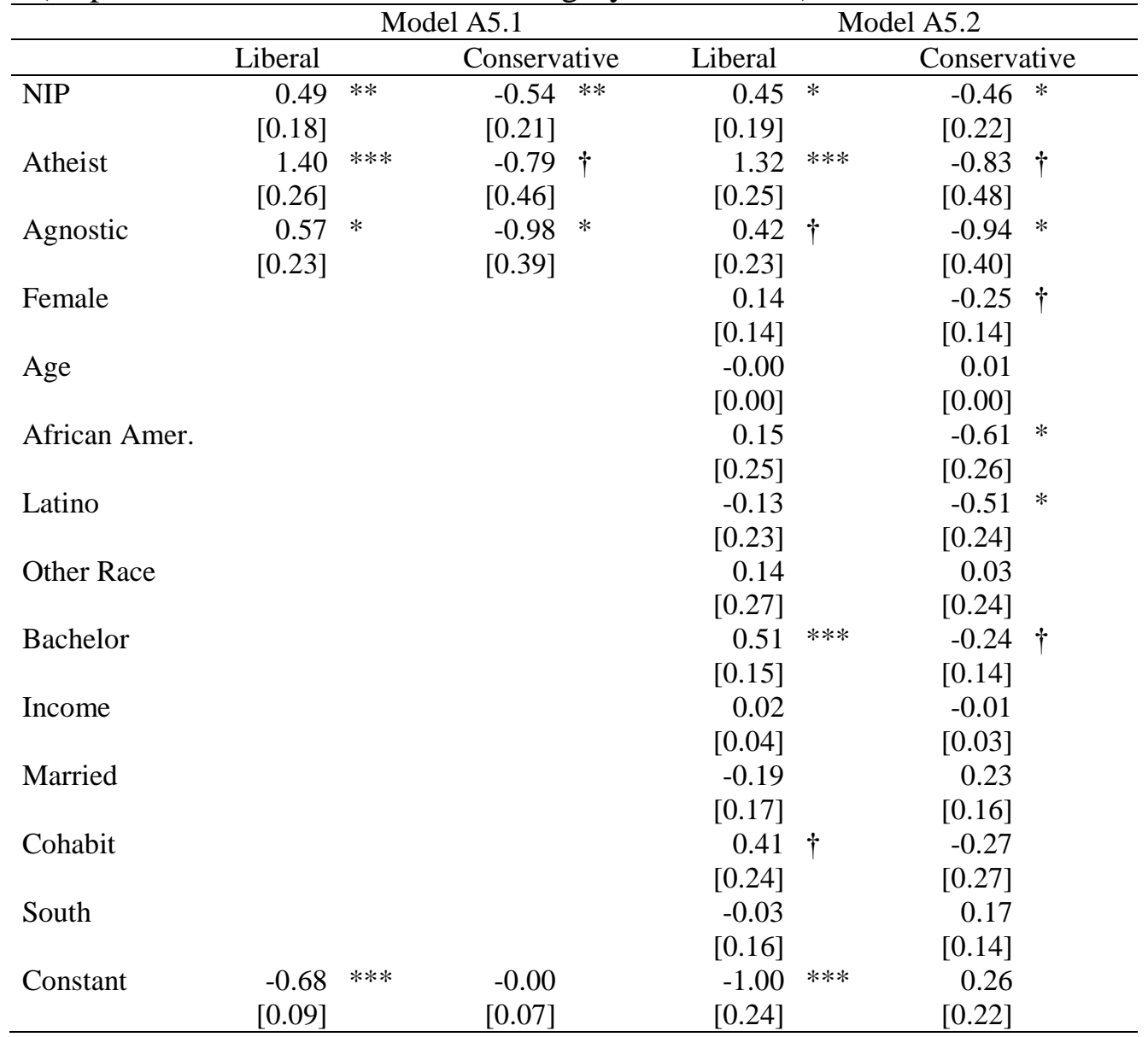

Notes: Table reports coefficients, standard errors in brackets, $\mathrm{N}=4,093$.

$\dagger \mathrm{p}<.1,{ }^{*} \mathrm{p}<.05,{ }^{* *} \mathrm{p}<.01,{ }^{* * *} \mathrm{p}<.001$ (two-tailed test) 
Table A6. Binary Logistic Regressions of Republican/Lean Republican and View that Party Represents Interests of People Like Them

\begin{tabular}{|c|c|c|c|c|c|c|c|c|c|c|c|c|}
\hline \multirow[b]{3}{*}{ NIP } & \multicolumn{4}{|c|}{ Republican/Lean Republican } & \multicolumn{4}{|c|}{$\begin{array}{l}\text { Democratic Party Represents } \\
\text { Interests of People Like Them }\end{array}$} & \multicolumn{4}{|c|}{$\begin{array}{l}\text { Republican Party Represents } \\
\text { Interests of People Like Them }\end{array}$} \\
\hline & \multicolumn{2}{|c|}{ Model A6.1 } & \multicolumn{2}{|c|}{ Model A6.2 } & \multicolumn{2}{|c|}{ Model A6.3 } & \multicolumn{2}{|c|}{ Model A6.4 } & \multicolumn{2}{|c|}{ Model A6.5 } & \multicolumn{2}{|c|}{ Model A6.6 } \\
\hline & -0.67 & $* * *$ & -0.73 & $* * *$ & 0.59 & $* * *$ & 0.58 & $* *$ & -0.84 & $* * *$ & -0.88 & $* * *$ \\
\hline & {$[0.17]$} & & {$[0.18]$} & & {$[0.16]$} & & {$[0.18]$} & & {$[0.16]$} & & {$[0.17]$} & \\
\hline \multirow[t]{2}{*}{ Atheist } & -1.53 & $* * *$ & -1.99 & $* * *$ & 0.61 & $*$ & 0.89 & $* * *$ & -1.21 & $* * *$ & -1.52 & $* * *$ \\
\hline & {$[0.32]$} & & {$[0.32]$} & & {$[0.25]$} & & {$[0.26]$} & & {$[0.31]$} & & {$[0.30]$} & \\
\hline \multirow[t]{2}{*}{ Agnostic } & -1.19 & $* * *$ & -1.53 & $* * *$ & 0.93 & $* * *$ & 1.15 & $* * *$ & -1.21 & $* * *$ & -1.42 & $* * *$ \\
\hline & {$[0.26]$} & & {$[0.28]$} & & {$[0.22]$} & & {$[0.24]$} & & {$[0.28]$} & & [0.29] & \\
\hline \multirow[t]{2}{*}{ Female } & & & -0.45 & $* * *$ & & & 0.43 & $* * *$ & & & -0.36 & $* *$ \\
\hline & & & {$[0.13]$} & & & & {$[0.12]$} & & & & {$[0.12]$} & \\
\hline \multirow[t]{2}{*}{ Age } & & & 0 & & & & -0.00 & & & & -0.00 & \\
\hline & & & {$[0.00]$} & & & & {$[0.00]$} & & & & {$[0.00]$} & \\
\hline \multirow[t]{2}{*}{ African Amer. } & & & -2.56 & $* * *$ & & & 1.65 & $* * *$ & & & -2.14 & $* * *$ \\
\hline & & & {$[0.33]$} & & & & {$[0.24]$} & & & & {$[0.26]$} & \\
\hline \multirow[t]{2}{*}{ Latino } & & & -1.59 & $* * *$ & & & 1.32 & $* * *$ & & & -1.09 & $* * *$ \\
\hline & & & {$[0.22]$} & & & & {$[0.22]$} & & & & {$[0.21]$} & \\
\hline \multirow[t]{2}{*}{ Other Race } & & & -0.99 & $* * *$ & & & 0.87 & $* * *$ & & & -0.73 & $* *$ \\
\hline & & & {$[0.23]$} & & & & {$[0.22]$} & & & & {$[0.23]$} & \\
\hline \multirow[t]{2}{*}{ Bachelor } & & & -0.36 & $* *$ & & & 0.46 & $* * *$ & & & -0.65 & $* * *$ \\
\hline & & & {$[0.12]$} & & & & {$[0.12]$} & & & & {$[0.12]$} & \\
\hline \multirow[t]{2}{*}{ Income } & & & 0.02 & & & & -0.04 & & & & 0.04 & \\
\hline & & & {$[0.03]$} & & & & {$[0.03]$} & & & & [0.03] & \\
\hline \multirow[t]{2}{*}{ Married } & & & 0.26 & $\dagger$ & & & -0.2 & & & & 0.24 & \\
\hline & & & {$[0.14]$} & & & & {$[0.13]$} & & & & {$[0.15]$} & \\
\hline \multirow[t]{2}{*}{ Cohabit } & & & -0.2 & & & & 0.39 & & & & -0.38 & \\
\hline & & & {$[0.23]$} & & & & {$[0.22]$} & & & & {$[0.22]$} & \\
\hline \multirow[t]{2}{*}{ South } & & & 0.32 & $*$ & & & -0.27 & $*$ & & & 0.35 & $* *$ \\
\hline & & & {$[0.14]$} & & & & {$[0.13]$} & & & & {$[0.13]$} & \\
\hline \multirow[t]{2}{*}{ Constant } & 0.02 & & 0.68 & $* *$ & -0.12 & & -0.61 & $* *$ & 0.12 & & 0.58 & $* *$ \\
\hline & {$[0.07]$} & & {$[0.21]$} & & [0.07] & & [0.19] & & {$[0.07]$} & & {$[0.20]$} & \\
\hline $\mathrm{N}$ & 4,018 & & 4,018 & & 4,073 & & 4,073 & & 4,073 & & 4,073 & \\
\hline
\end{tabular}

Notes: Table reports coefficients, standard errors in parentheses; $\mathrm{N}=4,073$.

$\dagger \mathrm{p}<.1, * \mathrm{p}<.05, * * \mathrm{p}<.01, * * * \mathrm{p}<.001$ (two-tailed test) 
Table A7. Multinomial Logistic Regressions of Vote Choice in 2016 Presidential Election (Dependent Variable Reference Category = Hillary Clinton)

\begin{tabular}{|c|c|c|c|c|c|c|c|c|}
\hline & \multicolumn{4}{|c|}{ Model A7.1 } & \multicolumn{4}{|c|}{ Model A7.2 } \\
\hline & \multicolumn{2}{|c|}{ Donald Trump } & \multicolumn{2}{|c|}{ Other Candidate } & \multicolumn{2}{|c|}{ Donald Trump } & \multicolumn{2}{|c|}{ Other Candidate } \\
\hline \multirow[t]{2}{*}{ NIP } & -1.05 & $* * *$ & 0.2 & & -1.22 & $* * *$ & -0.19 & \\
\hline & {$[0.22]$} & & {$[0.35]$} & & {$[0.23]$} & & [0.39] & \\
\hline \multirow[t]{2}{*}{ Atheist } & -1.62 & $* * *$ & 0.18 & & -2.11 & $* * *$ & -0.12 & \\
\hline & {$[0.38]$} & & [0.39] & & {$[0.34]$} & & [0.39] & \\
\hline \multirow[t]{2}{*}{ Agnostic } & -1.28 & $* * *$ & -0.07 & & -1.59 & $* * *$ & -0.52 & \\
\hline & {$[0.36]$} & & {$[0.34]$} & & {$[0.41]$} & & {$[0.38]$} & \\
\hline \multirow[t]{2}{*}{ Female } & & & & & -0.69 & $* * *$ & -0.24 & \\
\hline & & & & & {$[0.16]$} & & {$[0.21]$} & \\
\hline \multirow[t]{2}{*}{ Age } & & & & & 0 & & -0.03 & $* * *$ \\
\hline & & & & & {$[0.00]$} & & {$[0.01]$} & \\
\hline \multirow[t]{2}{*}{ African Amer. } & & & & & -3.51 & $* * *$ & -1.45 & $* *$ \\
\hline & & & & & {$[0.60]$} & & {$[0.53]$} & \\
\hline \multirow[t]{2}{*}{ Latino } & & & & & -1.55 & $* * *$ & -1.15 & $* *$ \\
\hline & & & & & {$[0.34]$} & & {$[0.43]$} & \\
\hline \multirow[t]{2}{*}{ Other Race } & & & & & -0.76 & $*$ & -0.56 & \\
\hline & & & & & {$[0.32]$} & & {$[0.38]$} & \\
\hline \multirow{2}{*}{ Bachelor } & & & & & -1.16 & $* * *$ & -0.45 & $*$ \\
\hline & & & & & {$[0.16]$} & $\dagger$ & {$[0.20]$} & \\
\hline \multirow[t]{2}{*}{ Income } & & & & & 0.07 & & -0.12 & $*$ \\
\hline & & & & & {$[0.04]$} & & {$[0.06]$} & \\
\hline \multirow[t]{2}{*}{ Married } & & & & & 0.55 & $* *$ & 0.42 & \\
\hline & & & & & {$[0.18]$} & & {$[0.29]$} & \\
\hline \multirow[t]{2}{*}{ Cohabit } & & & & & 0 & & 0.42 & \\
\hline & & & & & {$[0.33]$} & & {$[0.40]$} & \\
\hline \multirow[t]{2}{*}{ South } & & & & & 0.26 & & -0.01 & \\
\hline & & & & & [0.17] & & {$[0.26]$} & \\
\hline \multirow[t]{2}{*}{ Constant } & 0.2 & $* *$ & -1.59 & $* * *$ & 0.78 & $* *$ & -0.62 & $\dagger$ \\
\hline & {$[0.08]$} & & {$[0.14]$} & & {$[0.26]$} & & {$[0.35]$} & \\
\hline
\end{tabular}

Notes: Table reports coefficients, standard errors in brackets, $\mathrm{N}=3,055$.

$\dagger \mathrm{p}<.1, * \mathrm{p}<.05, * * \mathrm{p}<.01, * * * \mathrm{p}<.001$ (two-tailed test) 